\title{
Liquid Fermentation of Ganoderma applanatum and Antioxidant Activity of Exopolysaccharides
}

\author{
LIU Zhong-hua*, HOU Xiao-ge, Zhao Jin-hui and HE Le \\ College of Life Science and Agronomy, Zhoukou Normal University, Zhoukou, Henan, 466000, China
}

\begin{abstract}
The medium composition and fermentation conditions of Ganoderma applanatum(GA) strain were optimized by the liquid shake flask fermentation, and the antioxidant activity of exopolysaccharides was investigated. The results showed that the optimal conditions of the liquid fermentation of GA strain were as follows: Carbon source was corn powder, nitrogen source was soy powder, the initial $\mathrm{pH}$ was 6.0 , the inoculum size was $8 \%$, the fermentation temperature was $32^{\circ} \mathrm{C}$, the fermentation time was $7 \mathrm{~d}$. The exopolysaccharides of GA strain could scavenge hydroxyl radicals(HR) and superoxide anion radicals(SAR), and the concentration of exopolysaccharides was positively related to the antioxidant activity.
\end{abstract}

Keywords: Antioxidant activity, GA, liquid fermentation.

\section{INTRODUCTION}

Ganoderma applanatum(GA) is a kind of large edible fungi, having a variety of active ingredients such as polysaccharide, triterpenoids, amino acid, polypeptide. These active ingredients have anti-tumor, anti-virus, anti-cancer, lowering blood glucose, regulating blood pressure and other pharmacological activities [1-4]. Liquid submerged fermentation technology is a modern large-scale industrial method to product fungi and their metabolites, which has the advantages of short period, simple process, low cost, high yield, suitable for industrial production etc. It was reported that culture solution produced by submerged fermentation of GA has rich nutrition and medicinal value [5-8]. Producing by liquid submerged fermentation method, GA mycelium and culture solution processed and extracted can be made of food additive and health care food. This has the positive practical significance.

The research integrated the liquid fermentation conditions of GA, which aimed to provide a theory evidence for liquid fermentation process control of GA and accumulate some fundamental and elementary investigations for largescale industrial production. In addition, the study had further investigated the antioxidant activity of exopolysaccharides, which offered evidences to further develop functional food of GA.

\section{MATERIALS AND METHODS}

\subsection{Materials}

Bacterial strain. GA strain was provided by College of Life Science and Agronomy, Zhoukou Normal University.

Culture medium. Agarslantculture-medium(PDA medium) was composed of $20 \%$ boiled juice filtering of peeled

*Address correspondence to this author at the College of Life Science and Agronomy, Zhoukou Normal University, Zhoukou, Henan, 466000, China; Tel: 13839439312; E-mail: 1zh.hzl@163.com potatos, $2 \%$ sucrose, $0.3 \% \mathrm{KH}_{2} \mathrm{PO}_{4}, 0.15 \% \mathrm{MgSO}_{4}, 2 \%$ agar, natural $\mathrm{pH}$. Culture medium of liquid strain was composed of $1 \%$ glucose, $2 \%$ sucrose, $1 \%$ peptone, $0.5 \%$ beef extract, $0.1 \% \mathrm{KH}_{2} \mathrm{PO}_{4}, 0.15 \% \mathrm{MgSO}_{4}$, natural $\mathrm{pH}$.

Preparation of GA strain. GA strain, which was propagated on PDA medium for $5 \mathrm{~d}$ at $28^{\circ} \mathrm{C}$, was grown for $4 \mathrm{~d}$ at $28^{\circ} \mathrm{C}$ with the shaking speed of $100 \mathrm{r} / \mathrm{min}$ prior to inoculation, according to the user's manual instructions. Then, the strain had been obtained and stored at $4^{\circ} \mathrm{C}$ in the refrigerator for further sutdy.

\subsection{Methods}

Determination of mycelial biomass. Mycelium was obtained by removing supernatant of fermentation broth centrifuged at $3000 \mathrm{r} / \mathrm{min}$ for $15 \mathrm{~min}$. Mycelium which was dried at $50^{\circ} \mathrm{C}$ after washing with distilled water several times was weighed.

Determination of raw exopolysaccharides. The supernatant, which was decanted after the fermentation broth centrifuged, was added 3 times volume of $95 \%$ ethanol and was set aside for $24 \mathrm{~h}$ at $50^{\circ} \mathrm{C}$. After centrifuging at $4000 \mathrm{r} / \mathrm{min}$ for $20 \mathrm{~min}$, the precipitate dried to constant weight was weighed.

Optimization of fermentation conditions. Carbon source, nitrogen source, initial $\mathrm{pH}$, inoculums size, fermentation temperature, fermentation time were investigated respectively to study their effect on shake flash fermentation of GA by measuring mycelial biomass and raw exopolysaccharides.

Determination of antioxidant activity of exopolysaccharides. The scavenging effect of exopolysaccharides on HRs was measured with the reaction system of fenton [9]. The scavenging effect of exopolysaccharides on SARs was measured with the methods of pyrogallol autoxidation [10]. 


\section{RESULTS AND ANALYSIS}

\subsection{Optimization on the Liquid Fermentation Conditions of GA Strain}

Effect of carbon source on shake flash fermentation of GA. Fermentation broth was prepared with $1 \%$ peptone, $0.5 \%$ beef extract, $0.1 \% \mathrm{KH}_{2} \mathrm{PO}_{4}, 0.15 \% \mathrm{MgSO}_{4}$ and $3 \%$ carbon source changed as glucose, maltose, sucrose, corn powder, soluble starch. $8 \%$ of GA strain were added and cultured at $28^{\circ} \mathrm{C}$ for $5 \mathrm{~d}$. Then, Mycelial biomass and raw exopolysaccharides were determined (Table $\mathbf{1}$ ).

It was shown in Table $\mathbf{1}$ that using corn powder as the sole carbon source, mycelial biomass and raw exopolysaccharides produced by GA were significantly higher than those of the other carbon sources produced. And corn powder with relatively low cost, wide source, was suitable for use in production. Thus the optimal carbon source was corn powder.

Table 1. Effect of carbon source on shake flash fermentation of GA.

\begin{tabular}{|c|c|c|}
\hline $\begin{array}{c}\text { Carbon } \\
\text { source }\end{array}$ & $\begin{array}{c}\text { Mycelial biomass } \\
(\mathbf{g} / \mathbf{1 0 0} \mathbf{~ m L})\end{array}$ & $\begin{array}{c}\text { The content of raw exopoly- } \\
\text { saccharides }(\mathrm{g} / \mathbf{1 0 0} \mathbf{~ m L})\end{array}$ \\
\hline \hline Glucose & $0.181 \pm 0.012 \mathrm{~d}$ & $0.166 \pm 0.005 \mathrm{~b}$ \\
\hline Maltose & $0.345 \pm 0.008 \mathrm{~b}$ & $0.074 \pm 0.005 \mathrm{~d}$ \\
\hline Sucrose & $0.237 \pm 0.013 \mathrm{c}$ & $0.149 \pm 0.002 \mathrm{c}$ \\
\hline Corn powder & $0.435 \pm 0.001 \mathrm{a}$ & $0.420 \pm 0.007 \mathrm{a}$ \\
\hline $\begin{array}{c}\text { Soluble } \\
\text { starch }\end{array}$ & $0.085 \pm 0.019 \mathrm{e}$ & $0.066 \pm 0.008 \mathrm{~d}$ \\
\hline
\end{tabular}

Effect of nitrogen source on shake flash fermentation of GA strain. Fermentation broth was prepared with $3 \%$ corn powder, $0.1 \% \mathrm{KH}_{2} \mathrm{PO}_{4}, \quad 0.15 \% \mathrm{MgSO}_{4}$ and $1.5 \%$ nitrogen source changed as peptone, yeast extract, beef extract, bran, soy powder.. $8 \%$ of GA strain were added and cultured at $28^{\circ} \mathrm{C}$ for $5 \mathrm{~d}$. Then, Mycelial biomass and raw exopolysaccharides were determined. The results were shown at Table 2 .

Table 2. Effect of nitrogen source on shake flash fermentation of GA.

\begin{tabular}{|c|c|c|}
\hline $\begin{array}{c}\text { Nitrogen } \\
\text { Source }\end{array}$ & $\begin{array}{c}\text { Mycelial biomass } \\
(\mathbf{g} / \mathbf{1 0 0} \mathbf{~ m L})\end{array}$ & $\begin{array}{c}\text { The content of raw exopoly- } \\
\text { saccharides }(\mathbf{g} / \mathbf{1 0 0} \mathbf{~ m L})\end{array}$ \\
\hline \hline Peptone & $0.181 \pm 0.008 \mathrm{c}$ & $0.064 \pm 0.002 \mathrm{~d}$ \\
\hline Yeast extract & $0.356 \pm 0.006 \mathrm{~b}$ & $0.150 \pm 0.003 \mathrm{c}$ \\
\hline Beef extract & $0.204 \pm 0.008 \mathrm{c}$ & $0.167 \pm 0.001 \mathrm{c}$ \\
\hline Bran & $0.338 \pm 0.021 \mathrm{~b}$ & $0.478 \pm 0.001 \mathrm{a}$ \\
\hline Soy powder & $0.485 \pm 0.009 \mathrm{a}$ & $0.356 \pm 0.021 \mathrm{~b}$ \\
\hline
\end{tabular}

Table 2 showed that the effect of bran and soy powder utilized by GA was significantly higher than that of yeast extract, beef extract and peptone, while the difference between the soy powder and bran was significant. Both soy powder and bran are easily available raw materials. They could be selected according to desired product fermented by GA strain in practical production. If the desired product was mycelium, soy powder was the best nitrogen source; If the desired product was exopolysaccharides, bran was the best nitrogen source.

Effect of initial pH on shake flash fermentation of GA strain. Fermentation broth was prepared with $3 \%$ corn powder, $1.5 \%$ soy powder $0.1 \% \mathrm{KH}_{2} \mathrm{PO}_{4}, 0.15 \% \mathrm{MgSO}_{4}$ and initial $\mathrm{pH}$ changed as $4.0 \cdot 5.0 \cdot 6.0 \cdot 7.0 \div 8.0 .8 \%$ of GA strain were added and cultured at $28^{\circ} \mathrm{C}$ for $5 \mathrm{~d}$. Then, Mycelial biomass and raw exopolysaccharides were determined (Table 3).

Table 3. Effect of initial PH on shake flash fermentation of GA.

\begin{tabular}{|c|c|c|}
\hline PH value & $\begin{array}{c}\text { Mycelial biomass } \\
(\mathbf{g} / \mathbf{1 0 0} \mathbf{~} \mathbf{L})\end{array}$ & $\begin{array}{c}\text { The content of raw exopoly- } \\
\text { saccharides }(\mathrm{g} / \mathbf{1 0 0} \mathbf{~ m L})\end{array}$ \\
\hline \hline 4.0 & $0.383 \pm 0.003 \mathrm{c}$ & $0.277 \pm 0.017 \mathrm{e}$ \\
\hline 5.0 & $0.449 \pm 0.016 \mathrm{~b}$ & $0.442 \pm 0.015 \mathrm{c}$ \\
\hline 6.0 & $0.541 \pm 0.014 \mathrm{a}$ & $0.511 \pm 0.001 \mathrm{a}$ \\
\hline 7.0 & $0.365 \pm 0.031 \mathrm{c}$ & $0.480 \pm 0.004 \mathrm{~b}$ \\
\hline 8.0 & $0.324 \pm 0.009 \mathrm{c}$ & $0.316 \pm 0.007 \mathrm{~d}$ \\
\hline
\end{tabular}

It was shown in Table $\mathbf{3}$ that, with the rise of $\mathrm{pH}$ value, the mycelial biomass and raw exopolysaccharides increased gradually. At $\mathrm{pH}$ 6.0, both mycelial biomass and raw exopolysaccharides reached to the peak, and then decreased correspondingly with $\mathrm{pH}$ value rise. Therefore, GA strain is suitable to grow in acidic environment. The most suitable $\mathrm{pH}$ value for GA was 6.0.

Effect of inoculum size on shake flash fermentation of GA strain. Fermentation broth was prepared with $3 \%$ corn powder, $1.5 \%$ soy powder $0.1 \% \mathrm{KH}_{2} \mathrm{PO}_{4}, 0.15 \% \mathrm{MgSO}_{4}$ and initial pH6.0. Inoculum size of GA strain changed as $4 \%$, $6 \%, 8 \%, 10 \%$ and $12 \%$ were added and cultured at $28^{\circ} \mathrm{C}$ for 5 d. Then, Mycelial biomass and raw exopolysaccharides were determined (Table 4) .

Table 4 showed that when the inoculums size was $8 \%$ or $10 \%$, mycelial biomass fermented by GA strain was significantly higher than the other. While the difference between $8 \%$ and $10 \%$ was not significant. When the inoculum size was $6 \%$ or $8 \%$, the content of raw exopolysaccharides fermented by GA strain was significantly higher than the other. While the difference between $6 \%$ and $8 \%$ was not significant. All things considered, the suitable inoculum size was $8 \%$.

Effect of fermentation time on shake flash fermentation of GA strain. Fermentation broth was prepared with $3 \%$ corn powder, $1.5 \%$ soy powder $0.1 \% \mathrm{KH}_{2} \mathrm{PO}_{4}$, $0.15 \% \mathrm{MgSO}_{4}$ and initial pH6.0. $8 \%$ of GA strain were added and cultured at $28^{\circ} \mathrm{C}$, and fermentation time was changed as $1 \mathrm{~d}, 3 \mathrm{~d}, 5 \mathrm{~d}, 7 \mathrm{~d}$ and $9 \mathrm{~d}$. Then, Mycelial biomass and raw exopolysaccharides were determined. The results were shown at Table 5. 
Table 4. Effect of inoculum size on shake flash fermentation of GA.

\begin{tabular}{|c|c|c|}
\hline $\begin{array}{c}\text { Inoculum } \\
\text { size(\%) }\end{array}$ & $\begin{array}{c}\text { Mycelial biomass } \\
(\mathbf{g} / \mathbf{1 0 0} \mathbf{~} \mathbf{L})\end{array}$ & $\begin{array}{c}\text { The content of raw exopolysac- } \\
\text { charides }(\mathbf{g} / \mathbf{1 0 0} \mathbf{~} \mathbf{L})\end{array}$ \\
\hline \hline 4 & $0.269 \pm 0.009 \mathrm{~d}$ & $0.377 \pm 0.002 \mathrm{c}$ \\
\hline 6 & $0.392 \pm 0.005 \mathrm{c}$ & $0.552 \pm 0.008 \mathrm{a}$ \\
\hline 8 & $0.546 \pm 0.004 \mathrm{a}$ & $0.541 \pm 0.003 \mathrm{a}$ \\
\hline 10 & $0.556 \pm 0.005 \mathrm{a}$ & $0.517 \pm 0.007 \mathrm{~b}$ \\
\hline 12 & $0.442 \pm 0.014 \mathrm{~b}$ & $0.388 \pm 0.011 \mathrm{c}$ \\
\hline
\end{tabular}

Table 5. Effect of fermentation time on shake flash fermentation of GA.

\begin{tabular}{|c|c|c|}
\hline $\begin{array}{c}\text { Fermentation } \\
\text { time(d) }\end{array}$ & $\begin{array}{c}\text { Mycelial bio- } \\
\text { mass (g /100 } \\
\mathbf{~ m L )}\end{array}$ & $\begin{array}{c}\text { The content of raw } \\
\text { exopolysaccharides (g/100 } \\
\mathbf{m L})\end{array}$ \\
\hline \hline 1 & $0.179 \pm 0.002 \mathrm{c}$ & $0.169 \pm 0.009 \mathrm{e}$ \\
\hline 3 & $0.307 \pm 0.003 \mathrm{~b}$ & $0.334 \pm 0.018 \mathrm{~d}$ \\
\hline 5 & $0.560 \pm 0.001 \mathrm{a}$ & $0.427 \pm 0.015 \mathrm{c}$ \\
\hline 7 & $0.556 \pm 0.006 \mathrm{a}$ & $0.588 \pm 0.010 \mathrm{a}$ \\
\hline 9 & $0.554 \pm 0.001 \mathrm{a}$ & $0.537 \pm 0.008 \mathrm{~b}$ \\
\hline
\end{tabular}

Table 5 showed that the longer the fermentation time, the higher was the mycelial biomass. The mycelial biomass increased to a peak value at $5 \mathrm{~d}$, but then did not changed with the extension of time, which meant the growth curve of GA strain reached the stationary phase after fermenting for $5 \mathrm{~d}$; The content of raw exopolysaccharides increased significantly with the increase of fermentation time. The content increased to a peak value at $7 \mathrm{~d}$, but then lowered down significantly with the extension of time. The time taken to reach the top amount of mycelial biomass was not consistent with the time taken to reach the top amount of exopolysaccharides. Therefore, the growth of mycelia and secretion of exopolysaccharides was not synchronized, and the secretion of exopolysaccharides lagged some time. All things considered, the suitable fermentation time was $7 \mathrm{~d}$.

Effect of fermentation temperature on shake flash fermentation of GA strain. Fermentation broth was prepared with $3 \%$ corn powder, $1.5 \%$ soy powder $0.1 \% \mathrm{KH}_{2} \mathrm{PO}_{4}$, $0.15 \% \mathrm{MgSO}_{4}$ and initial $\mathrm{pH} 6.0 .8 \%$ of GA strain were added and cultured for $7 \mathrm{~d}$, and fermentation temperature was changed as $22^{\circ} \mathrm{C}, 25^{\circ} \mathrm{C}, 28^{\circ} \mathrm{C}, 32^{\circ} \mathrm{C}$ and $35^{\circ} \mathrm{C}$. Then, Mycelial biomass and raw exopolysaccharides were determined (Table 6).

It was shown in Table 6 that, effect of fermentation temperature on shake flash fermentation of GA was significant. Mycelial biomass and raw exopolysaccharides increased significantly with the increase of fermentation temperature. The content increased to a peak value at $32^{\circ} \mathrm{C}$, but then lowered down with the rise of temperature. Its reason might be that high temperature caused the strain premature aging, and metabolites can also be reduced accordingly. Therefore, the optimum fermentation temperature was $32^{\circ} \mathrm{C}$.

Table 6. Effect of fermentation temperature on shake flash fermentation of GA.

\begin{tabular}{|c|c|c|}
\hline $\begin{array}{c}\text { Fermentation } \\
\text { temperature (d) }\end{array}$ & $\begin{array}{c}\text { Mycelial biomass } \\
(\mathbf{g} / \mathbf{1 0 0} \mathbf{~ m L})\end{array}$ & $\begin{array}{c}\text { The content of raw exopoly- } \\
\text { saccharides } \mathbf{( g / 1 0 0 ~} \mathbf{~ m L})\end{array}$ \\
\hline \hline 22 & $0.341 \pm 0.015 \mathrm{e}$ & $0.357 \pm 0.017 \mathrm{e}$ \\
\hline 25 & $0.391 \pm 0.009 \mathrm{~d}$ & $0.431 \pm 0.023 \mathrm{~d}$ \\
\hline 28 & $0.547 \pm 0.007 \mathrm{~b}$ & $0.581 \pm 0.002 \mathrm{~b}$ \\
\hline 32 & $0.659 \pm 0.009 \mathrm{a}$ & $0.631 \pm 0.011 \mathrm{a}$ \\
\hline 35 & $0.431 \pm 0.021 \mathrm{c}$ & $0.490 \pm 0.004 \mathrm{c}$ \\
\hline
\end{tabular}

\subsection{Antioxidant Activity of Exopolysaccharides}

It was shown in Table 7 that, the exopolysaccharides could scavenge HRs and SARs, and the more radicals were scavenged with the increase of concentration of raw exopolysaccharides. It indicated that its scavenging activity might be related to exopolysaccharides. When the concentration of exopolysaccharides was $1.2 \mathrm{mg} / \mathrm{mL}$, the ratio of HRs scavenged had exceeded $50 \%$; When the concentration of exopolysaccharides was $1.8 \mathrm{mg} / \mathrm{mL}$, the ratio of SARs scavenged had reached $50 \%$, too.

Table 7. The scavenging effect of exopolysaccharides on HRs and SARs.

\begin{tabular}{|c|c|c|}
\hline $\begin{array}{l}\text { The concentration } \\
\text { of exopolysaccha- } \\
\text { rides }(\mathrm{mg} / \mathrm{mL})\end{array}$ & $\begin{array}{c}\text { The ratio of } \mathrm{HRs} \\
\text { scavenged }(\%)\end{array}$ & $\begin{array}{c}\text { The ratio of SARs } \\
\text { scavenged }(\%)\end{array}$ \\
\hline 0.5 & $33.2 \pm 0.9 \mathrm{e}$ & $22.0 \pm 0.5 \mathrm{e}$ \\
\hline 0.8 & $46.6 \pm 0.4 d$ & $31.7 \pm 0.4 \mathrm{~d}$ \\
\hline 1.2 & $54.0 \pm 0.1 \mathrm{c}$ & $41.1 \pm 0.3 c$ \\
\hline 1.8 & $61.1 \pm 0.3 b$ & $50.1 \pm 0.1 \mathrm{~b}$ \\
\hline 2.5 & $63.9 \pm 0.1 \mathrm{a}$ & $58.8 \pm 0.1 \mathrm{a}$ \\
\hline
\end{tabular}

\section{CONCLUSION}

The medium composition and fermentation conditions for the production of GA were studied. The optimal liquid fermentation parameters of GA were as follows: Carbon source was corn powder, nitrogen source was soy powder, the initial $\mathrm{pH}$ was 6.0 , the inoculums size was $8 \%$, the fermentation temperature was $32^{\circ} \mathrm{C}$, the fermentation time was 7 d. In addition, the antioxidant activity of exopolysaccharides which were produced by the fermentation of GA was also studied.The result showed that the exopolysaccharides had the ability to scavenge HRs and SARs, and the concentration of exopolysaccharides was positively related to the antioxidant activity. 


\section{CONFLICT OF INTEREST}

The authors confirm that this article content has no conflict of interest.

\section{ACKNOWLEDGEMENTS}

This work is supported by the Key Project of Scientific and Technological Research of the Education Department of Henan, China (No.13A416110).

\section{REFERENCES}

[1] Z.B. Zhou, H.X. Ma, and T. Bau, "A review of researches on chemical composition and pharmacology of Ganoderma applanatum," Journal of Rungal Research, vol. 3, pp. 35-42, 2005.

[2] H.M. Pan, and Y.J. Yu, "The effects of applanatum pat polysaccharide and zhuling polysaccharide on TNF- $\alpha$ expression of mouse HepA tumor cells," Chinese Journal of Primary Medicine and Pharmacy, vol. 9, pp. 486-487, 2002.

[3] R.H. Li, Y. Wang, L.H. Zheng, C.J. Zhang, H.Y. Xu, R. Wang, and Y.B. Zhang, "The effects of GAPS on inhibiting gastric cancer cell line MGC-803 proliferation and PDGFR- $\beta$ expression," J Med Res, vol. 38, pp. 52-54, 2009.
[4] Z.H. Liu, X.G. Hou, W.L. Pei, R.F. Lv, and H.J. Du, "Fermentation characteristics of Ganoderma applanatum,"China Brewing, vol. 223, pp. 130-132, 2010.

[5] Y. Luo, Z.J. Zhang, S.F. Li, and L.W. Yang, "Studies on liquid fermentation of Ganoderma Lucidum,"Academic Periodical of Farm Products Processing, pp. 50-52, 2007.

[6] Y.R. Gao, and Y.M. Lu, "Study on submerged fermentation of Ganoderma Lucidum hypha,"China Brewing, pp. 18-20, 2006.

[7] H. He, and B.J. Xie, "Studies on the enzymolysis and the free radicals scavenging activities of water extract for Ganoderma Lucidum," Food and Fermentation Industries, vol. 27, pp. 11-14, 2000.

[8] H. Jozica, B. Marin, and W. Branha, "Effects of fundal polysaccharides from Ganoderma lucidum submerged biomass cultivation," Food Technol Biotechnol, vol. 39, pp. 27-33, 2000.

[9] Z.J. Zhang, F.H. Wang, and X.X. Zeng, "In vitro antioxidant activities and hepatoprotective effects of polysaccharides from Allium macrostemon Bunge," Modern Food Science and Technology, vol. 30, pp. 1-6, 2014.

[10] L.X. Zhang, and L.J. Zhao, "Study on antioxidant activity of Flammulina velutipes polysaccharide," Southwest China Journal of Agricultural Sciences, vol. 27, pp. 240-243, 2014.

Received: April 10, 2015

Revised: May 20, 2015

Accepted: June 15, 2015

(C) Zhong-hua et al.; Licensee Bentham Open.

This is an open access article licensed under the terms of the (https://creativecommons.org/licenses/by/4.0/legalcode), which permits unrestricted, noncommercial use, distribution and reproduction in any medium, provided the work is properly cited. 